\title{
擋乱による円管内乱流の発達の操縦
}

\section{The Management of the development of Turbulent Pipe Flow by a Manipulator}

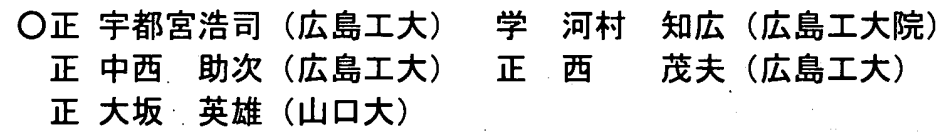

\begin{abstract}
Koji UTSUNOMIYA, Hiroshima Institute of Technology, 2-1-1, Miyake, Saeki-ku, Hiroshima Tomohiro KAWAMURA, Hiroshima Institute of Technology Suketsugu NAKANISHI, Hiroshima Institute of Technology Shigeo NISHI, Hiroshima Institute of Technology Hideo OSAKA, Yamaguchi University, 2-16-1, Tokiwadai, Ube
\end{abstract}

Key Words: Pipe Flow, Turbulent Flow, Flow Control, Inlet Length, Ring Type Manipulator

\section{1. 锖贯}

本研究はパルス的擋乱による円管内乱流の発達の操縦を 目的とする。助走区閒の初期段階に宇都宮等 ${ }^{(1)}$ の報告と同一 の 3 種類の単独擋乱リングを導入し、十分発達した円管内流 れへの発達について測定する。擋乱に対する流れの応答と発 達の操縋(制御)の機構や、剥離せん断層の性質を調査する。

\section{2. 实跧装目 およひ方法}

2-1 実験装固実験装置の概略、主要記号及び座標系を図 1 に示す。測定管路は内径 $\mathrm{D}=2 \mathrm{R}=80 \mathrm{~mm}$ で、座標系はリ ングの先端位置から流れ方向に $\mathrm{x}_{0}$ 、管壁から半径方向に $\mathrm{y}$ と した。また管中心速度はUc、断面平均速度はUa である。

\section{2-2 擋乱リング 擋乱リング(以後 MR と略記は管入口部} 先端から $175 \mathrm{~mm}$ の位置に挿入(境界層厚さは $\delta_{0} \fallingdotseq 8 \mathrm{~mm}$ ) し た。断面形状は高さ $\mathrm{h}=1 \mathrm{~mm}$ 、長さ $\mathrm{w}=1.5 \mathrm{~mm}$ の長方形で、 次の半径方向位置に設置した。

Case I：MRを壁面に付着させた場合

Case II：境界層外端に相当する位置に挿入した場合

Case III：ポテンシャルコア領域に挿入した場合

2-3 実䀫条件およひ测定方法 実験は管径レイノルズ数 $\mathrm{Re}=6 \times 10^{4}$ (宇都宮等は $\mathrm{Re}=9 \times 10^{4}$ )一定の条件で行った。測 定には主としてピトー管および熱線流速計を使用した。

2-4 非摚乱流場非摚乱流の場合、流れはおよそ70D の距 離で十分発達した流れて党に達している。

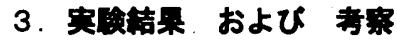

3-1 平均流場 Uc/Ua の分布等から見て Case I の場合、摚 乱直後で変化するものの、その後は非擋乱と同様である。こ れに対し Case II の場合発達は促進され、CaseIII の場合は遅延 する。また擋乱高さ位置に速度欠損が存在する。

3-2 乱流場の特徽流れ方向及び半径方向乱れ強さ分布 とレイノルズせん断応力分布について調査した。擋乱背後の 剥離せん断層では何れも大きな值を示すがすぐに減衰する。 3-3 港乱の影零 図 2 に MR 背後の剥離せん断層での- $\overline{\mathrm{uv}}$ のピーク值と、 $\overline{\mathrm{q}}^{2} / \mathrm{Uc}$ 及び- $\overline{\mathrm{u}} \overline{\mathrm{v}}$ のピーク位置を示す。ピーク 值の流れ方向変化を見ると、Case I の場合、(- $\overline{\mathrm{uv}}) \mathrm{pc}$ の值は MR 直後で最も大きな值を示すが、減衰も早い。Case II の場 合、MR 直後では Case I より值は小さく、また擋乱直後で急 減少する。Case III の場合、擋乱直後では Case II の場合とやや 異なる值を示す。次にピークや零の值をとる位置を見ると、 Case II の場合、 $\mathrm{x}_{0} / \mathrm{D}<0.5$ では $(-\overline{\mathrm{uv}}) \mathrm{pc}$ と $(-\overline{\mathrm{uv}}) \mathrm{pw}$ のほぼ中心

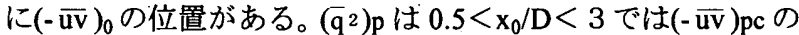
方に近づく。Case III の場合、剥離せん断層は対称的な分布傾

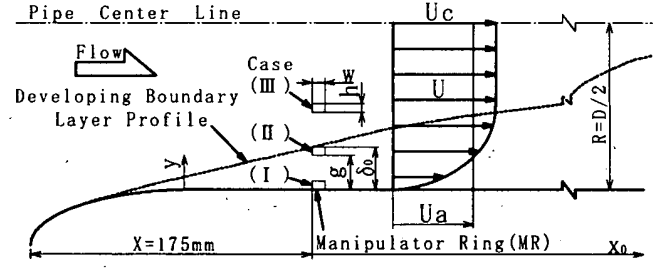

Fig.1 Experimental apparatus, coordinate system and nomenclatures

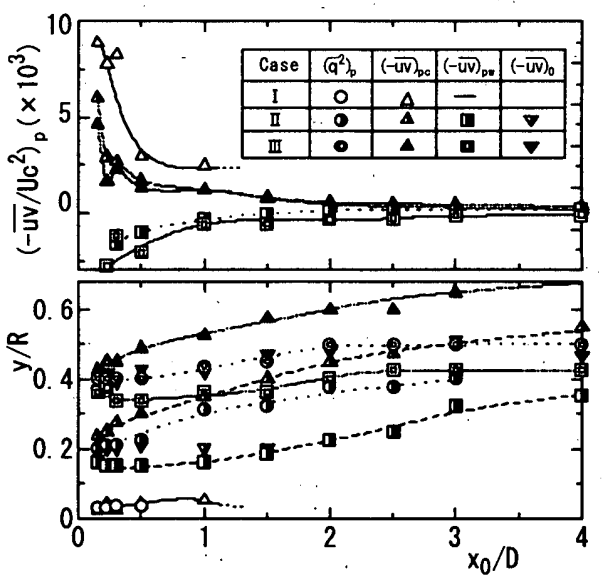

Fig. 2 Characteristics of the shear layer

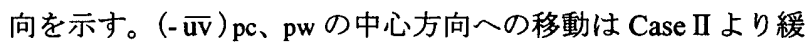
やかで、両者に傾向差がある。

\section{4. 结量}

円管内乱流の管路入口部分に同一断面形状の単独擋乱リ ングを 3 種類の高さ位置に導入し、各々の場合の流れの変化 を測定した。発達の操縦(制御)を試みる場合、適切な位置に 設置の必要があることや、摚乱背後の剥離せん断層の領域や 壁面近傍の流れに各 Case 間で差が生じること、Case I より Case III の方が長く剥離せん断層が維持されることを明らか にした。従って、MR 直後の壁面近傍や MR 背後の乱流構造 の差により、流れの発達に差が生じている。

\section{文䔉}

(1) 宇都宮浩司·大坂英雄·羽野茂浩, 機論, 64-625, B(1998), 3286-3292.

(2) Klein,A., Trans.ASME, J.Fluids Eng., 103(1981), 243-249. 